\title{
Non-contiguous finished genome sequence and description of Bartonella senegalensis sp. nov.
}

\author{
Oleg Mediannikov ${ }^{1}$, Khalid El Karkouri' ${ }^{1}$, Georges Diatta ${ }^{1}$, Catherine Robert ${ }^{1}$, Pierre-Edouard \\ Fournier ${ }^{1}$ and Didier Raoult ${ }^{1 *}$ \\ ${ }^{1}$ URMITE, Aix-Marseille Université, Marseille, France, and Campus commun UCAD-IRD \\ d'Hann, Dakar, Senegal \\ *Correspondence: Didier Raoult (didier.raoult@gmail.com)
}

Keywords: Bartonella senegalensis, genome, Senegal, soft tick, Ornithodoros sonrai

Bartonella senegalensis sp. nov. strain $\mathrm{OSO}^{\top}$ is the type strain of $B$. senegalensis sp. nov., a new species within the genus Bartonella. This strain, whose genome is described here, was isolated in Senegal from the soft tick Ornithodoros sonrai, the vector of relapsing fever. $B$. senegalensis is an aerobic, rod-shaped, Gram-negative bacterium. Here we describe the features of this organism, together with the complete genome sequence and its annotation. The 1,966,996 bp-long genome contains 1,710 protein-coding and 46 RNA genes, including 6 rRNA genes.

\section{Introduction}

Bartonella is the only genus of the family Bartonellaceae of Alphaproteobacteria. To date, 29

Bartonella species have been validly published $[1,2]$, and many isolates have yet to be described. These bacteria are facultative intracellular pathogens, many of which infect erythrocytes [3]. At least 13 Bartonella species are associated with human diseases. B. bacilliformis, $B$. quintana and $B$. henselae, are relatively common human pathogens and cause Carrión's disease, trench fever and cat scratch fever, respectively. Different species of Bartonella are also associated with chronic bacteremia and/or endocarditis, bacillary angiomatosis, peliosis hepatitis, retinitis, uveitis, and myocarditis [4].

The epidemiological cycle of bartonellae consists of a reservoir host, which is a vertebrate with a chronic intravascular infection and sustained bacteremia, and a vector (usually a blood-sucking arthropod such as fleas, sandflies or lice) that transfers the bacteria from the reservoir to a susceptible host. Bartonella species are typically associated with a specific primary host; e.g., $B$. henselae is commonly found in domestic and wild felids all over the world, including Africa [5-7], whereas $B$. bacilliformis is human-specific. Animal hosts of bartonellae include dogs, rabbits, coyotes, foxes, cattle, deer, elk and multiple rodent species [6,810]. For most pathogenic bartonellae (except $B$. bacilliformis and B. quintana), humans are accidental (secondary) hosts [6].

In 2003, La Scola et al. proposed a multilocus sequence analysis based on 4 genes and one intergenic spacer as a tool for the description of new Bartonella species [11]. Among these genetic markers, two, i.e., glt $A$ and $r p o B$, were particularly discriminatory, with new Bartonella isolates considered as new species if they exhibit $<96.0 \%$ and $<95.4 \%$ sequence identity with other validly published species for the 327- and 825-bp fragments of the glt $A$ and $r p o B$ genes, respectively [2,11-13]. This strategy of combining sequences from several genes, usually housekeeping genes, is congruent with the "gold-standard" DNA-DNA reassociation for several bacterial genera [14].

In this study, we used La Scola's criteria and described the genome sequence as well as main phenotypic characteristics of strain $0502^{\mathrm{T}}$. Here, we present a summary classification and a set of features for B. senegalensis sp. nov. strain $0 \mathrm{~S} 02^{\mathrm{T}}$ together with the description of the complete genomic sequence and annotation. These characteristics support the definition of the species $B$. senegalensis. 


\section{Classification and features}

Fifteen adult Ornithodoros sonrai soft ticks were collected in 2008 from rodent burrows in the Soulkhou Thissé village (a rural village in the Guinean-Sudanian zone in Senegal) as part of a prospective study on tick-borne relapsing fever in West Africa. Ticks were preserved at room temperature for 40 days without feeding prior to further testing. The isolation of Bartonella strains from ticks was performed as described previously [15] and the results will be reported elsewhere. Strain OS02 (Table 1) was obtained in June 2009 from a single tick following a 7-day incubation at $37^{\circ} \mathrm{C}$ in $5 \% \mathrm{CO}_{2}$-enriched atmosphere on Columbia agar (BioMerieux, Marcy l'Etoile, France).

Table 1. Classification and general features of Bartonella senegalensis strain $\mathrm{OSO}^{\top}{ }^{\top}$.

\begin{tabular}{|c|c|c|c|}
\hline MIGS ID & Property & Term & Evidence code $^{\mathrm{a}}$ \\
\hline & \multirow{8}{*}{ Current classification } & Domain Bacteria & TAS [16] \\
\hline & & Phylum Proteobacteria & TAS [17] \\
\hline & & Class Alphaproteobacteria & TAS $[3,18]$ \\
\hline & & Order Rhizobiales & TAS $[19,20]$ \\
\hline & & Family Bartonellaceae & TAS [21-23] \\
\hline & & Genus Bartonella & TAS $[21,23-26]$ \\
\hline & & Species Bartonella senegalensis & IDA \\
\hline & & Type strain OSO2 ${ }^{\top}$ & IDA \\
\hline & Gram stain & Negative & IDA \\
\hline & Cell shape & Rod & IDA \\
\hline & Motility & Non-motile & IDA \\
\hline & Sporulation & Non-sporulating & IDA \\
\hline & Temperature range & Mesophilic & IDA \\
\hline & Optimum temperature & $37^{\circ} \mathrm{C}$ & IDA \\
\hline MIGS-6.3 & Salinity & Growth in $\mathrm{BHI}$ medium $+5 \% \mathrm{NaCl}$ & IDA \\
\hline \multirow[t]{3}{*}{ MIGS-22 } & Oxygen requirement & Aerobic & IDA \\
\hline & Carbon source & Unknown & IDA \\
\hline & Energy source & Unknown & IDA \\
\hline MIGS-6 & Habitat & Tick gut & IDA \\
\hline \multirow[t]{3}{*}{ MIGS-15 } & Biotic relationship & Facultative intracellular & IDA \\
\hline & Pathogenicity & Unknown & \\
\hline & Biosafety level & 3 & \\
\hline MIGS-14 & Isolation & Soft tick Ornithodoros sonrai & IDA \\
\hline MIGS-4 & Geographic location & Senegal & IDA \\
\hline MIGS-5 & Sample collection time & May 2009 & IDA \\
\hline MIGS-4.1 & Latitude & $14^{\circ} 03^{\prime} \mathrm{N}$ & IDA \\
\hline MIGS-4.2 & Longitude & $15^{\circ} 31^{\prime} \mathrm{W}$ & IDA \\
\hline MIGS-4.3 & Depth & $\sim 0.5 \mathrm{~m}$ under surface & IDA \\
\hline MIGS-4.4 & Altitude & $45 \mathrm{~m}$ above sea level & IDA \\
\hline
\end{tabular}

${ }^{a}$ Evidence codes - IDA: Inferred from Direct Assay; TAS: Traceable Author Statement (i.e., a direct report exists in the literature); NAS: Non-traceable Author Statement (i.e., not directly observed for the living, isolated sample but based on a generally accepted property for the species or anecdotal evidence). Evidence codes come from the Gene Ontology project [27]. If the evidence is IDA, then the property was directly observed for a live isolate by one of the authors or an expert mentioned in the acknowledgements. 
In addition to glt $A$ and $r p o B$ partial gene sequencing, we also sequenced the intergenic transcribed spacer (ITS) and the 16S rRNA and ftsZ genes as previously described [11,26,28-30]. Strain OS02 T exhibited nucleotide sequence similarities of 85.7, 99.3, 94.5, 94.9 and $93.6 \%$ for the ITS, 16S rRNA, fts $Z$, glt $A$ and $r p o B$ genes, respectively, with $B$. henselae, the phylogenetically closest validly named Bartonella species (Figure 1).

Different growth temperatures $\left(32,37,42^{\circ} \mathrm{C}\right)$ were tested. Growth occurred only at $37^{\circ} \mathrm{C}$ in $5 \%$ $\mathrm{CO}_{2}$. Colonies were gray, opaque and $0.5 \mathrm{~mm}$ to 1 $\mathrm{mm}$ in diameter on blood-enriched Columbia agar.
A motility test was negative. Cells grown on agar are Gram negative and have a mean length and width of $1,254.4 \pm 329.3 \mathrm{~nm}$ and $533.3 \pm 100.5 \mathrm{~nm}$, respectively, by electron microscopy (Figure 2). No flagella or pili were observed.

Strain $0 S 02^{\mathrm{T}}$ exhibited neither catalase nor oxidase activity. Biochemical characteristics were assessed using an Anaerobe Identification Test Panel AN MicroPlate ${ }^{\mathrm{TM}}$ (Biolog Inc., Hayward, CA, USA). None of 95 biochemical tests available (including D-mannose, D-fructose and D-galactose) were positive. Similar profiles were previously observed for other Bartonella species [13].

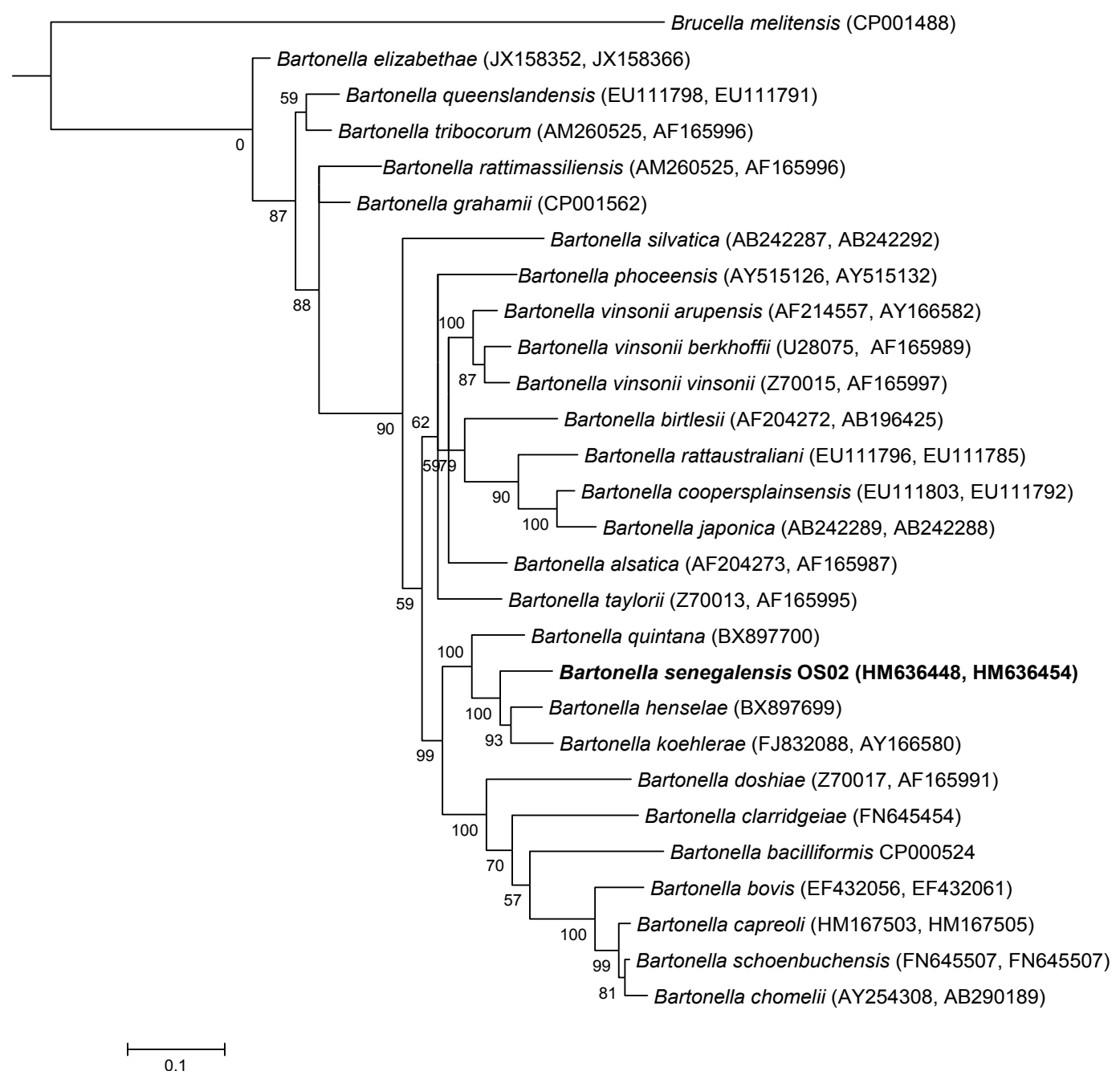

Figure 1. Phylogenetic tree highlighting the position of Bartonella senegalensis strain OSO2 relative to other type strains within the genus Bartonella. Concatenated gltA and rpoB sequences were aligned using CLUSTALW and phylogenetic inferences obtained using Bayesian phylogenetic analysis [31] with the TOPALi 2.5 software (Biomathematics and Statistics Scotland, Edinburgh, UK) with the integrated MrBayes application [32] with the GTR+Г substitution model. GenBank $a$ cession numbers are indicated in parentheses as $(g / t A, r p o B)$. Numbers at the nodes are bootstrap values obtained by repeating the analysis 100 times to generate a majority consensus tree. There were a total of 1,044 positions in the final dataset. The scale bar indicates a $10 \%$ nucleotide sequence divergence. 


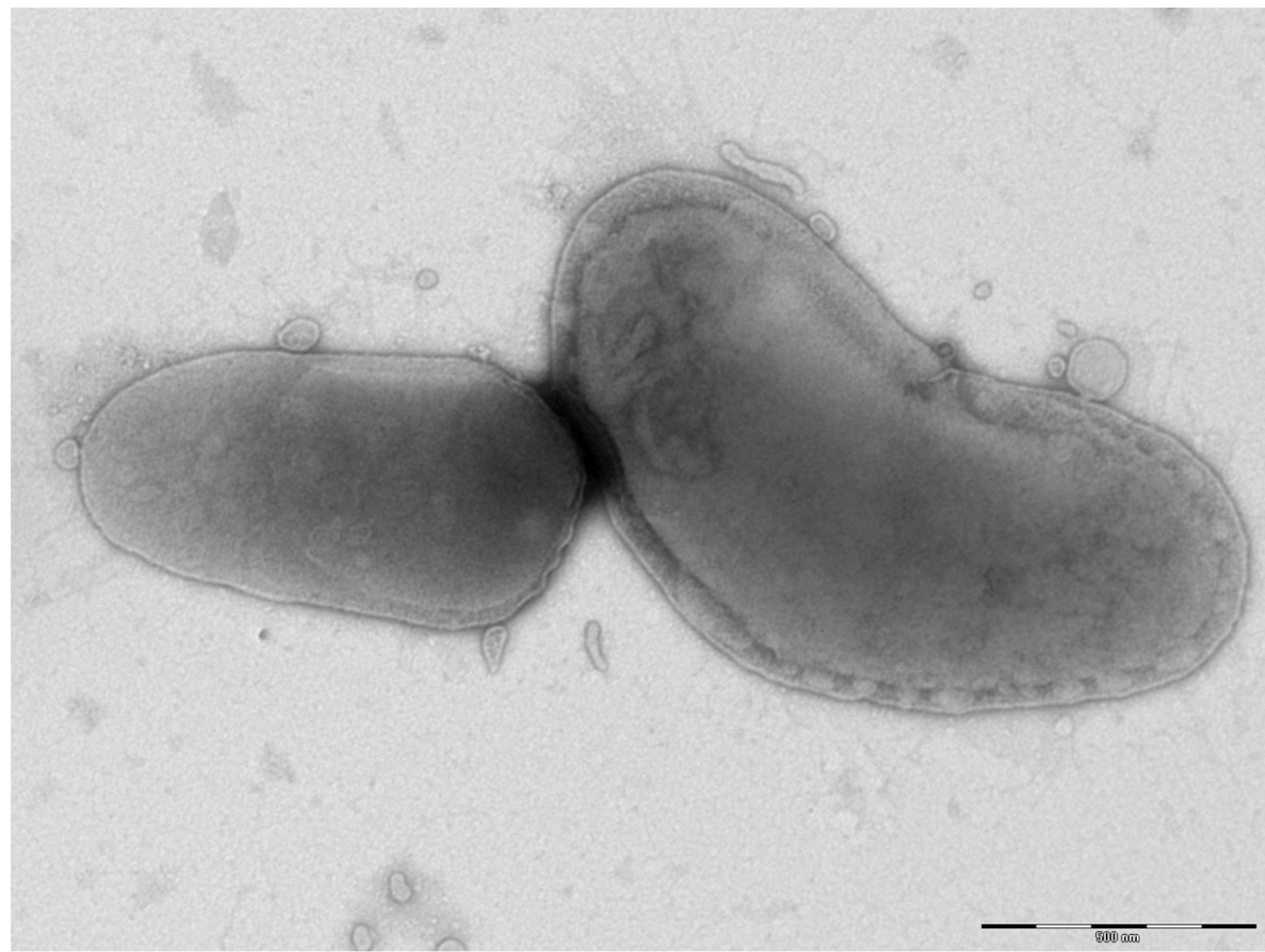

Figure 2. Transmission electron micrograph of B. senegalensis strain $\mathrm{OSO}^{\top}{ }^{\top}$, using a Morgagni 268D (Philips) transmission electron microscope at an operating voltage of $60 \mathrm{kV}$. The scale bar represents $500 \mathrm{~nm}$.

Matrix-assisted laser desorption/ionization timeof-flight (MALDI-TOF) mass spectrometry protein analysis was carried out as previously described [33]. Five isolated colonies of strain $0 \mathrm{OS} 02^{\mathrm{T}}$ were deposited as individual spots on the MALDI target plate. Each smear was overlaid with $2 \mu \mathrm{L}$ of matrix solution (a saturated solution of alpha-cyano-4hydroxycinnamic acid) in 50\% acetonitrile/2.5\% trifluoroacetic acid, and allowed to dry for five minutes. Measurements were performed with a Microflex spectrometer (Bruker). The five OS02T spectra were imported into the MALDI BioTyper software (version 2.0, Bruker) and analyzed by standard pattern matching (with default parameter settings) against the main spectra of 4,613 bacteria in the BioTyper database and of 19 Bartonella species in our own database. The identification method included the $\mathrm{m} / \mathrm{z}$ from 3,000 to $15,000 \mathrm{Da}$. For every spectrum, a maximum of 100 peaks were taken into account and compared with the spectra in the database. For strain $0 S 02^{\mathrm{T}}$, the scores obtained were always below 1.5 (a score < 1.7 did not enable an identification), suggesting that our isolate was not a member of a known species. We added the spectrum from strain $0 S 02^{\mathrm{T}}$ to the database (Figure 3).

\section{Genome sequencing information Genome project history}

The organism was selected for sequencing on the basis of the similarity of its $16 \mathrm{~S}$ rRNA, ITS, ftsZ, glt $A$ and $r p o B$ to other members of the genus Bartonella. Nucleotide sequence similarity levels of these genes suggested that strain $0 \mathrm{SO}^{\mathrm{T}}$ represents a new species in the genus Bartonella. A summary of the project information is shown in Table 2. The GenBank accession number is CALV00000000, and the entry consists of 99 contigs ( $\geq 200 \mathrm{bp}$ ) and 9 scaffolds $(>1,500 \mathrm{bp})$. Table 2 shows the project information and its association with MIGS version 2.0 compliance. 


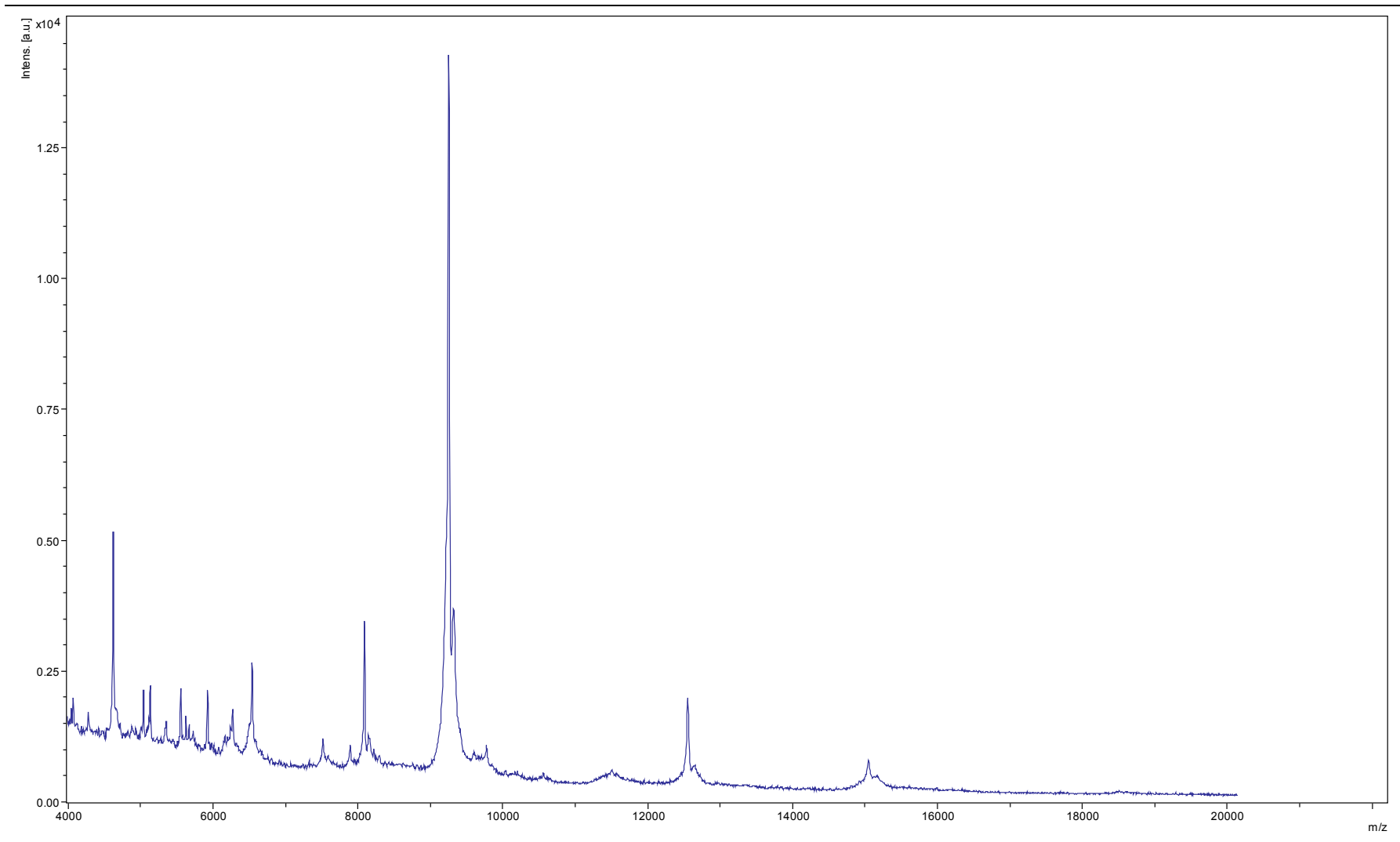

Figure 3. Reference mass spectrum from B. senegalensis strain $\mathrm{OSO2}^{\top}$. Spectra from 5 individual colonies were compared, and a reference spectrum was generated.

Table 2. Project information

\begin{tabular}{lll}
\hline MIGS ID & Property & Term \\
\hline MIGS-31 & Finishing quality & High-quality draft \\
MIGS-28 & Libraries used & One paired-end 3-kb library \\
MIGS-29 & Sequencing platforms & 454 GS FLX Titanium \\
MIGS-31.2 & Fold coverage & 30× \\
MIGS-30 & Assemblers & Newbler version 2.5.3 \\
& & Prodigal \\
MIGS-32 & Gene calling method & CALV00000000 \\
& Genbank ID & August 17, 2012 \\
& Genbank Date of Release & Biodiversity of Ornithodoros sonrai flora \\
\hline
\end{tabular}




\section{Growth conditions and DNA isolation}

B. senegalensis sp. nov. strain OS02 ${ }^{\mathrm{T}}$ (DSM 23168; CSUR B623) was grown on $5 \%$ sheep bloodenriched Columbia agar at $37^{\circ} \mathrm{C}$ in a $5 \% \mathrm{CO}_{2}$ atmosphere. Four Petri dishes were spread and resuspended in $3 \times 100 \mu$ of G2 buffer (EZ1 DNA Tissue kit, Qiagen). A first mechanical lysis was performed by glass powder on the Fastprep-24 device (Sample Preparation system; MP Biomedicals, USA) using $2 \times 20$-second cycles. DNA was then treated with $2.5 \mu \mathrm{g} / \mu \mathrm{L}$ lysozyme (30 minutes at $37^{\circ} \mathrm{C}$ ) and extracted through the BioRobot EZ 1 Advanced XL (Qiagen). The DNA was then concentrated and purified on a Qiamp kit (Qiagen). The yield and concentration were measured by the Quant-it Picogreen kit (Invitrogen) on the Genios Tecan fluorometer at $130.4 \mathrm{ng} / \mu \mathrm{l}$.

\section{Genome sequencing and assembly}

DNA $(5 \mu \mathrm{g})$ was mechanically fragmented on a Hydroshear device (Digilab, Holliston, MA, USA) with an enrichment size of 3-4 kb. The DNA fragmentation was visualized using the Agilent 2100 BioAnalyzer on a DNA labchip 7500 with an optimal size of $3.475 \mathrm{~kb}$. The library was constructed according to the 454 GS FLX Titanium paired-end protocol. Circularization and nebulization were performed and generated a pattern with an optimum at $641 \mathrm{bp}$. After PCR amplification over 17 cycles followed by double size selection, the single-stranded paired-end library was then quantified with the BioAnalyzer on a DNA labchip RNA pico 6,000 at $323 \mathrm{pg} / \mu \mathrm{L}$. The library concentration equivalence was calculated as $9.24 \mathrm{E}+08$ molecules/ $\mu \mathrm{L}$. The library was stored at $20^{\circ} \mathrm{C}$ until further use.

The library was clonally amplified with $1 \mathrm{cpb}$ and $1.5 \mathrm{cpb}$ in 4 and 3 emPCR reactions, respectively, with the GS Titanium SV emPCR Kit (Lib-L) v2 (Roche). The yields of the $1 \mathrm{cpb}$ and $1.5 \mathrm{cpb}$ emPCR were determined to be $3.08 \%$ and $8 \%$, respectively. After amplification, 790,000 beads from the 2 emPCR conditions were loaded on a $1 / 4$ region on the GS Titanium PicoTiterPlate PTP Kit $70 \times 75$ and sequenced with the GS FLX Titanium Sequencing Kit XLR70 (Roche). The run was analyzed on the cluster through the gsRunBrowser and Newbler assembler (Roche). A total of 200,243 passed filter wells were obtained and generated $57.62 \mathrm{Mb}$ of DNA sequence with an average length of $287 \mathrm{bp}$. The passed filter sequences were assembled using Newbler with $90 \%$ identity and $40 \mathrm{bp}$ for overlap requirements. The final assembly identified 9 scaffolds and 63 large contigs $(\geq 1,500 \mathrm{bp})$, generating a genome size of $1.98 \mathrm{Mb}$, which corresponds to $29.10 \times$ equivalent genome.

\section{Genome annotation}

Open reading frames (ORFs) were predicted using PRODIGAL [34] with default parameters, but predicted ORFs were excluded if they spanned a sequencing gap region. The predicted bacterial protein sequences were searched against the GenBank database [35] using BLASTP and the Clusters of Orthologous Groups (COG) database using COGNITOR [36]. The prediction of RNA genes, i.e., rRNAs, tRNAs and other RNAs, was performed using the RNAmmer [37] and ARAGORN [38] algorithms. The transmembrane helices and signal peptides were identified using TMHMM [39] and SignalP [40], respectively.

\section{Genome properties}

The genome is 1,966,996 bp long (one chromosome, no plasmids) with a $38.6 \% \mathrm{G}+\mathrm{C}$ content (Table 3, Figure 4). Of the 1,756 predicted genes, 1,710 were protein-coding genes, and 46 were RNAs ( 2 rRNA operons and 40 tRNA genes). A total of 997 genes (58.3\%) were assigned a putative function. The remaining genes were annotated as either hypothetical proteins or proteins of unknown functions. The distribution of genes into COGs functional categories is presented in Table 4. The properties and the statistics of the genome are summarized in Tables 3 and 4 .

\section{Insights from the genome sequence}

Compared to B. henselae strain Houston (GenBank accession number NC_005956), its closest phylogenetic neighbor, $B$. senegalensis strain $0 \mathrm{~S} 02^{\mathrm{T}}$ had a larger genome $(1,966,996$ and $1,931,047 \mathrm{bp}$, respectively), more genes (1,756 and 1,491 genes, respectively) and a higher $\mathrm{G}+\mathrm{C}$ content (38.6 and $38 \%$, respectively). The protein-coding genes present in $B$. senegalensis but absent or split in $B$. henselae included multidrug-efflux transporter, membrane protein formate-tetrahydrofolate ligase, formate-tetrahydrofolate ligase, glycoside hydrolase family 3-like, glycoside hydrolase family 3-like, putative major facilitator superfamily, SAMdependent methyltransferases, resolvases, toxinantitoxin modules, transposases, ubiquinolcytochrome C reductase, LeuA2, and phage proteins, as well as several hypothetical proteins. 
Table 3. Nucleotide content and percentage of the genome

\begin{tabular}{lrr}
\hline Attribute & Value & \% $^{\text {of }}$ total $^{\mathbf{a}}$ \\
\hline Genome size (bp) & $1,966,996$ & 100 \\
DNA coding region $(b p)$ & $1,488,480$ & 75.7 \\
DNA G+C content (bp) & 760,125 & 38.6 \\
Total genes & 1,756 & 100 \\
RNA genes & 46 & 2.6 \\
Protein-coding genes & 1,710 & 97.4 \\
Protein with predicted function & 997 & 58.3 \\
Genes assigned to COG & 1,425 & 83 \\
Genes with peptide signal & 81 & 47.3 \\
Genes with transmembrane helices $(\geq 3)$ & 178 & 10.4 \\
\hline
\end{tabular}

${ }^{a}$ The total is based on either the size of the genome in base pairs or the total number of protein coding genes in the annotated genome.

Table 4. Number of genes associated with the 25 general COG functional categories ${ }^{\dagger}$.

\begin{tabular}{crrl}
\hline Code & Value & \%age & Description \\
\hline J & 143 & 8.36 & Translation \\
A & 0 & 0 & RNA processing and modification \\
K & 76 & 4.44 & Transcription \\
L & 98 & 5.73 & Replication, recombination and repair \\
B & 0 & 0 & Chromatin structure and dynamics \\
D & 22 & 1.29 & Cell cycle control, mitosis and meiosis \\
Y & 0 & 0 & Nuclear structure \\
V & 10 & 0.58 & Defense mechanisms \\
T & 38 & 2.22 & Signal transduction mechanisms \\
M & 89 & 5.20 & Cell wall/membrane biogenesis \\
N & 3 & 0.18 & Cell motility \\
Z & 0 & 0 & Cytoskeleton \\
W & 6 & 0.35 & Extracellular structures \\
U & 68 & 3.98 & Intracellular trafficking and secretion \\
O & 76 & 4.44 & Posttranslational modification, protein turnover and chaperones \\
C & 81 & 4.74 & Energy production and conversion \\
G & 60 & 3.51 & Carbohydrate transport and metabolism \\
E & 124 & 7.25 & Amino acid transport and metabolism \\
F & 43 & 2.51 & Nucleotide transport and metabolism \\
H & 57 & 3.33 & Coenzyme transport and metabolism \\
I & 42 & 2.46 & Lipid transport and metabolism \\
P & 74 & 4.33 & Inorganic ion transport and metabolism \\
Q & 15 & 0.88 & Secondary metabolites biosynthesis, transport and catabolism \\
R & 183 & 10.70 & General function prediction only \\
S & 117 & 6.84 & Function unknown \\
X & 449 & 26.26 & Not in COGs \\
\hline & & & \\
\hline & &
\end{tabular}

${ }^{\dagger}$ The total is based on the total number of protein coding genes in the annotated genome. 


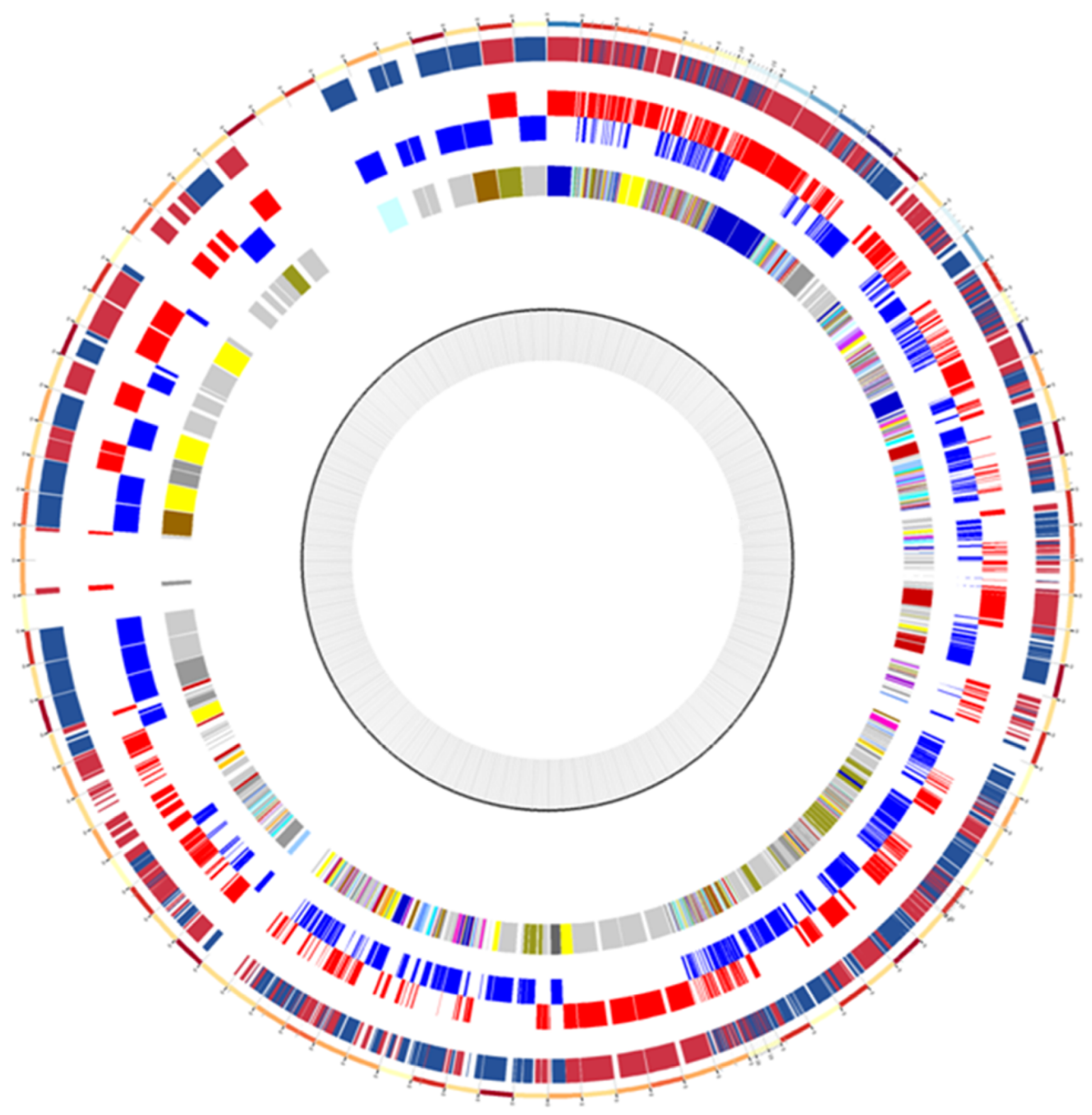

Figure 4. Circular map of the genome. From the outside in: genes on both forward and reverse strands, genes on the forward strand (red circle), genes on the reverse strand (blue circle) and genes colored by COG categories. 


\section{Conclusion}

On the basis of phylogenetic and genotypic analyses, we formally propose the creation of Bartonella senegalensis sp. nov., which contains strain $\mathrm{OSO2}^{\mathrm{T}}$. This bacterium was isolated in Senegal.

\section{Description of Bartonella senegalensis sp. nov.}

Bartonella senegalensis (se.ne.ga.len'sis. N.L. fem. adj. senegalensis referring to Senegal, the African country that is home to the Ornithodoros sonrai tick from which the type strain was isolated).

Colonies are opaque, grey and 0.5 to $1.0 \mathrm{~mm}$ in diameter on blood-enriched Columbia agar. Cells are rod-shaped without flagellae. Length and width are $1,254.4 \pm 329.3 \mathrm{~nm}$ and $533.3 \pm 100.5 \mathrm{~nm}$, respectively. Growth is only obtained at $37^{\circ} \mathrm{C}$.

\section{Acknowledgements}

We are grateful to Denis Pyak, Audrey Borg, and Geetha Subramanian for their technical help. The present work was partly supported by the Agence Nationale de Recherche grant 2010 MALEMAF (research on emergent

\section{References}

1. http://www.bacterio.cict.fr/b/bartonella.html.

2. Sato S, Kabeya H, Fujinaga $Y$, Inoue $K$, Une $Y$, Yoshikawa Y, Maruyama S. Bartonella jaculi sp. nov., Bartonella callosciuri sp. nov., Bartonella pachyuromydis sp. nov., and Bartonella acomydis sp. nov. isolated from wild Rodentia. [Epub ahead of print]. Int I Syst Evol Microbiol 2012; Aug 31, 2013.

3. Birtles RJ. Bartonellae as elegant hemotropic parasites. Ann N Y Acad Sci 2005; 1063:270-279. $\underline{\text { PubMed }}$ http://dx.doi.org/10.1196/annals.1355.044

4. Angelakis E, Billeter SA, Breitschwerdt EB, Chomel BB, Raoult D. Potential for tick-borne bartonelloses. Emerg Infect Dis 2010; 16:385391. PubMed http://dx.doi.org/10.3201/eid1603.091685

5. Chomel BB, Kasten RW, Henn JB, Molia S. Bartonella infection in domestic cats and wild felids. Ann N Y Acad Sci 2006; 1078:410-415. $\underline{\text { PubMed }}$ http://dx.doi.org/10.1196/annals.1374.080

6. Chomel BB, Kasten RW. Bartonellosis, an increasingly recognized zoonosis. J App/ Microbiol 2010;
Cells stain Gram-negative, are non-endosporeforming, and are non-motile. Catalase and oxidase activities are absent. No biochemical activity is observed using the Anaerobe Identification Test Panel AN MicroPlate.

The ITS, 16S rRNA, ftsZ, rpoB and gltA genes, and draft genome sequences are deposited in GenBank under accession numbers HM636451, HM636442, HM636445, HM636454, HM636448 and CALV00000000, respectively. The genome is $1,966,996 \mathrm{bp}$ long and contains 1,710 proteincoding and 46 RNA genes, including 6 rRNA genes. The $\mathrm{G}+\mathrm{C}$ content is $38.6 \%$. The type strain $\mathrm{OS}^{2} 2^{\mathrm{T}}$ (DSM 23168, CSUR B623) was isolated from an $O$. sonrai soft tick collected in a rodent burrow in a rural village in Senegal.

pathogens in Africa) and the Mediterranée Infection Foundation. The funders had no role in study design, data collection and analysis, decision to publish, or preparation of the manuscript.

109:743-750. PubMed

http://dx.doi.org/10.1111/j.13652672.2010.04679.x

7. Pretorius AM, Kuyl JM, Isherwood DR, Birtles RJ. Bartonella henselae in African lion, South Africa. Emerg Infect Dis 2004; 10:2257-2258. PubMed http://dx.doi.org/10.3201/eid1012.031054

8. Maillard R, Vayssier-Taussat M, Bouillin C, Gandoin C, Halos L, Chomel B, Piémont $Y$, Boulouis HJ. Identification of Bartonella strains isolated from wild and domestic ruminants by a single-step PCR analysis of the 16S-23S intergenic spacer region. Vet Microbiol 2004; 98:63-69. $\underline{\text { PubMed }}$ http://dx.doi.org/10.1016/j.vetmic.2003.09.022

9. Minnick MF, Anderson BE. The genus Bartonella. In: Dworkin M (editor), The Procaryotes, Springer, New York, 2006, p. 467-493.

10. Breitschwerdt EB, Kordick DL. Bartonella infection in animals: carriership, reservoir potential, pathogenicity, and zoonotic potential for human infection. Clin Microbiol Rev 2000; 13:428-438.

$\underline{\text { PubMed }}$

http://dx.doi.org/10.1128/CMR.13.3.428438.2000 
11. La Scola B, Zeaiter Z, Khamis A, Raoult D. Genesequence-based criteria for species definition in bacteriology: the Bartonella paradigm. Trends Microbiol 2003; 11:318-321. PubMed http://dx.doi.org/10.1016/S0966-842X(03)001434

12. Inoue $\mathrm{K}$, Kabeya $\mathrm{H}$, Shiratori H, Ueda K, Kosoy MY, Chomel BB, Boulouis HJ, Maruyama S. Bartonella japonica sp. nov. and Bartonella silvatica sp. nov., isolated from Apodemus mice. Int I Syst Evol Microbiol 2010; 60:759-763. PubMed http://dx.doi.org/10.1099/ijs.0.011528-0

13. Gundi VA, Taylor C, Raoult D, La Scola B. Bartonella rattaustraliani sp. nov., Bartonella queenslandensis sp. nov. and Bartonella coopersplainsensis sp. nov., identified in Australian rats. Int / Syst Evol Microbiol 2009; 59:29562961. PubMed http://dx.doi.org/10.1099/ijs.0.002865-0

14. Stackebrandt E, Frederiksen W, Garrity GM, Grimont PA, Kämpfer P, Maiden MC, Nesme X, Rosselló-Mora R, Swings J, Trüper HG, et al. Report of the ad hoc committee for the re-evaluation of the species definition in bacteriology. Int I Syst Evol Microbiol 2002; 52:1043-1047. PubMed http://dx.doi.org/10.1099/ijs.0.02360-0

15. Heller R, Riegel P, Hansmann Y, Delacour G, Bermond D, Dehio C, Lamarque F, Monteil H, Chomel B, Piémont Y. Bartonella tribocorum sp.nov., a new Bartonella species isolated from the blood of wild rats. Int I Syst Bacteriol 1998; 48:1333-1339. PubMed http://dx.doi.org/10.1099/00207713-48-4-1333

16. Woese CR, Kandler O, Wheelis ML. Towards a natural system of organisms: proposal for the domains Archaea, Bacteria, and Eukarya. Proc Natl Acad Sci USA 1990; 87:4576-4579. PubMed http://dx.doi.org/10.1073/pnas.87.12.4576

17. Garrity GM, Bell JA, Lilburn T. Phylum XIV. Proteobacteria phyl. nov. In: Garrity GM, Brenner DJ, Krieg NR, Staley JT (eds), Bergey's Manual of Systematic Bacteriology, Second Edition, Volume 2, Part B, Springer, New York, 2005, p. 1.

18. Garrity GM, Bell JA, Lilburn T. Class I. Alphaproteobacteria class. nov. In: Garrity GM, Brenner DJ, Krieg NR, Staley JT (eds), Bergey's Manual of Systematic Bacteriology, Second Edition, Volume 2, Part C, Springer, New York, 2005, p. 1.

19. Editor L. Validation List No. 107. List of new names and new combinations previously effectively, but not validly, published. Int / Syst Evol
Microbiol 2006; 56:1-6. PubMed

http://dx.doi.org/10.1099/ijs.0.64188-0

20. Kuykendall LD. Order VI. Rhizobiales ord. nov. In: Garrity GM, Brenner DJ, Krieg NR, Staley JT (eds), Bergey's Manual of Systematic Bacteriology, Second Edition, Volume 2, Part C, Springer, New York, 2005, p. 324.

21. Skerman VBD, McGowan V, Sneath PHA. Approved Lists of Bacterial Names. Int J Syst Bacteriol 1980; 30:225-420. http://dx.doi.org/10.1099/00207713-30-1-225

22. Gieszczykiewicz M. Zagadniene systematihki w bakteriologii - Zur Frage der Bakterien-Systematic. Bull Acad Pol Sci Biol 1939; 1:9-27.

23. Brenner DJ, O'Connor SP, Winkler HH, Steigerwalt AG. Proposals to unify the genera Bartonella and Rochalimaea, with descriptions of Bartonella quintana comb. nov., Bartonella vinsonii comb. nov., Bartonella henselae comb. nov., and Bartonella elizabethae comb. nov., and to remove the family Bartonellaceae from the order Rickettsiales. Int J Syst Bacteriol 1993; 43:777786. PubMed http://dx.doi.org/10.1099/00207713-43-4-777

24. Strong RP, Tyzzer EE, Sellards AW. Oroya fever. Second report. J Am Med Assoc 1915; 64:806808.

http://dx.doi.org/10.1001/jama.1915.0257036002 $\underline{2007}$

25. Weinman D. Genus I. Bartonella Strong, Tyzzer and Sellards 1915, 808. In: Buchanan RE, Gibbons NE (eds), Bergey's Manual of Determinative Bacteriology, Eighth Edition, The Williams and Wilkins Co., Baltimore, 1974, p. 904-905.

26. Birtles RJ, Harrison TG, Saunders NA, Molyneux $\mathrm{DH}$. Proposals to unify the genera Grahamella and Bartonella, with descriptions of Bartonella talpae comb. nov., Bartonella peromysci comb. nov., and three new species, Bartonella grahamii sp. nov., Bartonella taylorii sp. nov., and Bartonella doshiae sp. nov. Int / Syst Bacteriol 1995; 45:1-8. PubMed http://dx.doi.org/10.1099/00207713-45-1-1

27. Ashburner M, Ball CA, Blake JA, Botstein D, Butler H, Cherry JM, Davis AP, Dolinski K, Dwight SS, Eppig JT, et al. Gene ontology: tool for the unification of biology. The Gene Ontology Consortium. Nat Genet 2000; 25:25-29. PubMed http://dx.doi.org/10.1038/75556

28. Birtles RJ, Raoult D. Comparison of partial citrate synthase gene $(g / t A)$ sequences for phylogenetic analysis of Bartonella species. Int I Syst Bact 
1996; 46:891-897. PubMed

http://dx.doi.org/10.1099/00207713-46-4-891

29. Renesto P, Gouvernet J, Drancourt M, Roux V, Raoult D. Use of $r p o B$ gene analysis for detection and identification of Bartonella species. J Clin Microbiol 2001; 39:430-437. PubMed http://dx.doi.org/10.1128/JCM.39.2.430-437.2001

30. Zeaiter Z, Liang Z, Raoult D. Genetic classification and differentiation of Bartonella species based on comparison of partial ftsZ gene sequences. J Clin Microbiol 2002; 40:3641-3647. PubMed http://dx.doi.org/10.1128//CM.40.10.3641$\underline{3647.2002}$

31. Ronquist F, Huelsenbeck JP. MrBayes 3: Bayesian phylogenetic inference under mixed models. Bioinformatics 2003; 19:1572-1574. PubMed http://dx.doi.org/10.1093/bioinformatics/btg180

32. http://mrbayes.csit.fsu.edu.

33. Seng $P$, Drancourt M, Gouriet F, La SB, Fournier $\mathrm{PE}$, Rolain JM, Raoult D. Ongoing revolution in bacteriology: routine identification of bacteria by matrix-assisted laser desorption ionization timeof-flight mass spectrometry. Clin Infect Dis 2009; 49:543-551. PubMed http://dx.doi.org/10.1086/600885
34. Prokaryotic Dynamic Programming Genefinding Algorithm (PRODIGAL) http://prodigal.ornl.gov/.

35. http://www.ncbi.nlm.nih.gov/genbank. 28-122012

36. Tatusov RL, Galperin MY, Natale DA, Koonin EV. The COG database: a tool for genome-scale analysis of protein functions and evolution. Nucleic Acids Res 2000; 28:33-36. PubMed http://dx.doi.org/10.1093/nar/28.1.33

37. Lagesen K, Hallin P, Rodland EA, Staerfeldt HH, Rognes T, Ussery DW. RNAmmer: consistent and rapid annotation of ribosomal RNA genes. Nucleic Acids Res 2007; 35:3100-3108. PubMed http://dx.doi.org/10.1093/nar/gkm160

38. Laslett D, Canback B. ARAGORN, a program to detect tRNA genes and tmRNA genes in nucleotide sequences. Nucleic Acids Res 2004; 32:1116. PubMed http://dx.doi.org/10.1093/nar/gkh152

39. ТМНММ http://www.cbs.dtu.dk/services/TMHMM.

40. Petersen TN, Brunak S. von HG, Nielsen $\mathrm{H}$. SignalP 4.0: discriminating signal peptides from transmembrane regions. Nat Methods 2011; 8:785-786. PubMed http://dx.doi.org/10.1038/nmeth.1701 